\title{
PERHITUNGAN HARGA POKOK PENJUALAN DAN HARGA JUAL PRODUK UNTUK KEBERLANGSUNGAN UMKM DAPUR PIPIT, JAMBI
}

\author{
Joyce A. Turangan \\ Program Studi Manajemen, Fakultas Ekonomi dan Bisnis Universitas Tarumanagara, Jakarta \\ Email: joycet@fe.untar.ac.id
}

\begin{abstract}
This Abdimas activity is a request from the partner, named UMKM Dapur Pipit, which is engaged in the culinary business with superior pudding products. Although the partners' activities have been running, the owner feels that the pricing strategy that has been implemented so far and how the financial processing should be carried out is still lacking. The owner expects a training related to how to do good and correct financial management in order to achieve ideal financial management. Partners also expressed their desire to be able to understand the determination of the cost of production, selling prices, and how to manage the profits earned. The ABDIMAS team offers to provide solutions in the form of training in calculating the cost of goods sold and selling prices as the first step in managing the finances of UMKM that have been running so far. The output of this ABDIMAS activity is in addition to the output for partners in the form of understanding and ability to determine the cost of goods sold, selling price, and techniques for preparing simple financial reports for UMKM. Furthermore, a report on the implementation of ABDIMAS can be prepared which is published through national seminars within the scope of ABDIMAS or publications in national journals. The implementation method of this service is by conducting online training for partner leaders.
\end{abstract}

Keywords: Cost of good sold, selling price, financial report, UMKM

\begin{abstract}
ABSTRAK
Kegiatan Abdimas ini merupakan permintaan dari mitra, yaitu UMKM Dapur Pipit yang bergerak di bidang usaha kuliner dengan produk unggulan puding. Meskipun kegiatan dari mitra telah berjalan, namun pimpinan mitra merasakan masih kurang tepatnya strategi penentuan harga yang selama ini dijalankan serta bagaimana pengolahan keuangan yang seharusnya dilakukan. Mitra mengharapkan adanya suatu pelatihan terkait bagaimana melakukan pengelolaan keuangan yang baik dan benar agar tercapai suatu pengelolaan keuangan yang ideal. Mitra juga menyampaikan keinginan untuk dapat memahami penentuan harga pokok produksi, harga jual, dan bagaimana pengelolaan keuntungan yang diperoleh. Tim abdimas menawarkan untuk memberikan solusi berupa pelatihan perhitungan harga pokok penjualan dan harga jual sebagai langkah awal pengelolaan keuangan dari UMKM yang telah berjalan selama ini. Luaran dari kegiatan abdimas ini adalah selain luaran bagi mitra berupa pemahaman dan kemampuan menentukan harga pokok penjualan, harga jual, dan teknik penyusunan laporan keuangan sederhana bagi UMKM. Lebih lanjut dapat disusun suatu laporan pelaksanaan abdimas yang dipublikasikan melalui seminar nasional dalam lingkup abdimas atau publikasi pada jurnal nasional abdimas. Metode pelaksanaan dari abdimas ini adalah dengan dilakukan pelatihan secara daring pada pimpinan mitra.
\end{abstract}

Kata kunci: Harga pokok produksi, harga jual, laporan keuangan, UMKM

\section{PENDAHULUAN}

Dengan berlakunya ketentuan PPKM (Pemberlakukan Pembatasan Kegiatan Masyarakat), otomatis, kegiatan usaha dalam segala sektor akan terkena dampaknya dan tidak terkecuali bagi UMKM. Pembatasan kegiatan tersebut juga menjadikan sebagian besar usaha kuliner harus memanfaatkan seluruh strategi serta usaha yang dimilikinya agar dapat tetap bertahan meskipun dalam kondisi yang serba dibatasi. Strategi tersebut tidak hanya jeli dalam melihat jalur alternatif dalam memasarkan serta menjual produk, tetapi juga harus jeli dalam melakukan strategi penetapan harga yang bersaing. Banyak di antara para penggerak UMKM namun ternyata tidak dapat bertahan lama dengan yang biasanya dapat juga dikarenakan minimnya pemahaman dalam melakukan penentuan harga jual produknya. Ketidakpahaman tersebut dapat membuat penetapan harga penjualan menjadi sangat rendah atau sebaliknya cenderung sangat tinggi. Usaha yang sedang berjalan tentunya selalu memerlukan biaya yang dikeluarkan baik untuk pengenalan produk ke masyarakat, biaya penelitian \& pengembangan, biaya perbaikan produk 
yang kesemuanya ditujukan untuk dapat memenuhi permintaan pasar. Di lain pihak, ketidakpahaman dari pelaku UMKM akan perhitungan biaya produksi pada akhrinya akan berujung pada kesalahan dalam penentuan harga jual yang pada akhirnya akan mengakibatkan target keuntungan tidak dapat terpenuhi bahkan dapat mengakibatkan terancamnya keberlangsungan hidup UMKM.

Keuntungan merupakan target yang pada umumnya ingin diperoleh setiap jenis usaha termasuk oleh UMKM. Optimalisasi keuntungan juga merpakan suatu target pencapaian dari UMKM atas kegiatan bisnis yang dijalankannya. Semakin pesatnya suatu kegiatan bisnis sejalan dengan semakin ketatnya persaingan pasar menjadikan setiap kegiatan usaha dituntut untuk dapat lebih efektif dalam melakukan kegiatan bisnisnya agar produk yang dihasilkan memiliki kualitas dan daya jual yang baik di pasar, namun selain baiknya kualitas suatu produk, tentunya diperlukan penentuan harga yang tepat agar dapat tetap bertahan. Dalam penentuan harga yang tepat, tentunya suatu unit usaha mampu menerapkan suatu perhitungan yang akurat bagi produknya.

UMKM dalam hal ini seringkali kurang dapat dengan tepat menentukan harga bagi produknya, seringkali dikarenakan kurangnya kemampuan dalam segi pengelolan terutama saat melakukan penghitungan biaya produksi atas produk yang dihasilkan. Ketidakmampuan dalam melakukan penetapan harga pokok penjualan atas suatu produk yang dihasilkan akan berdampak pada terlalu rendahnya harga jual atau sebaliknya menjadi terlampau tinggi. Hal tersebut yang pada akhirnya dapat mempengaruhi besarnya keuntungan yang direncanakan dengan besaran dari keuntungan diperoleh pada akhirnya (Rudjito, 2003).

Ketatnya persaingan di dunia bisnis menuntut setiap penggerak UMKM untuk meningkatkan efisiensi dalam melakukan perhitungan biaya produksi. Perhitungan biaya produksi tersebut mutlah menjadi dalam penentuan harga jual produk yang ideal. Sehingga jika perhitungan biaya produksi dapat dilakukan secara tepat, maka akan diperoleh biaya produksi yang tepat pula. Salah satu cara yang dapat dilakukan dalam meningkatkatkan efisiensi biaya tersebut adalah dengan mengendalikan biaya produksi perusahaan.

Hammer, Carter, Usry (1994) mengemukakan bahwa biaya produksi terdiri dari tiga elemen yaitu Direct Materials (DM), Direct Labor (DL), dan Factory Overhead (FOH). Sementara untuk biaya produksi terebut dapat dibedakan menjadi Prime Cost dan Conversion Cost. Prime Cost adalah komponen biaya utama produk yang secara pada karya terdiri dari Direct Material dan Direct Labour, namun jika usahanya padat modal maka biaya utamanya Direct Material dan biaya overhead pabrik.

Hammer, Carter, dan Usry (1994) juga mengemukakan bahwa klasifikasi biaya terdiri dari biaya tetap, biaya variable, dan biaya semivariabel. Biaya tetap adalah biaya yang tidak berubah totalnya dalam aktivitas bisnis yang turun atau naik, biaya ini tetap dalam batas kapasitas normal (relevant range). Total biaya tetap tidak berubah namun biaya tetap per unitnya berubah, makin besar output yang dihasilkan membuat biaya tetap per unit makin kecil. Biaya variable adalah biaya yang totalnya berubah secara proporsional dengan naik / turunnya aktivitas bisnis. Total biaya variable berubah namun biaya variable per unitnya tetap dalam kisaran kapasitas normal (relevant range). Dalam kondisi tingkat aktivitas di atas kisaran yang relevan, perlu dihitung kembali tarif biaya variabel atau biaya variabel per unitnya. Biaya semivariabel adalah biaya yang memiliki unsur biaya tetap dan variabel, seperti: biaya listrik (abondemennya bersifat biaya tetap dan pemakaian per kwh bersifat biaya variabel. Dalam melakukan analisis, biaya semivariabel ini harus dipisah komponen fixed dan variable nya.

Djumali (2014) mengemukakan bahwa penetapan suatu harga pokok produksi yang pada akhirnya akan mempengaruhi harga jual serta perolehan laba suatu perusahaan hasilnya menunjukan bahwa penerapan metode pembiayaan variabel dalam penetapan harga pokok produksi akan menghasilkan suatu selisih harga yang lebih rendah. Sehingga penting untuk dicermati bahwa harga jual yang ditentukan dengan pendekatan full costing menjadi lebih tinggi 
yang akhirnya mempengaruhi harga jual yang juga lebih tinggi sehingga dapat menyulitkan perusahaan untuk memenangkan sebuah persaingan. Juga harus dipahami bahwa pengurangan biaya tetap tidak akan terjadi jika besarnya produksi berkurang atau bahkan tidak terjadi produksi atau nol maka biaya tetap akan selalu dikeluarkan, sehingga biaya tetap menjadi tidak relevan jika digunakan untuk pengambilan keputusan terkait penentuan harga jual produk. Selanjutnya, dalam penentuan harga pokok, dimana harga ini adalah biaya perolehan atas suatu barang. Para pelaku usaha dapat menentukan harga jual produk dengan meninjau harga pokok yang sudah ditambahkan dengan unsur biaya lainnya. Lebih lanjut, perhitungan keuntungan yang diharapkan melalui perolehan harga pokok.

Harga jual juga dapat ditinjau berdasarkan ketersediaan atas produk atau jasa sejenis di pasar. Jika produk atau jasa tersebut ternyata sulit untuk didapatkan dan dalam waktu bersamaan terjadi permintaan yang tinggi, maka pelaku usaha dapat menetapkan harga jual yang tinggi. Namun seandainya terjadi yang sebaliknya, maka dapat ditetapkan harga yang rendah. Selanjutnya harga jual atas suatu produk atau jasa juga sebaiknya menyamai harga pesaing. Pelaku usaha bebas menentukan harga jual yang seidikit lebih tinggi terutama jika memiliki keunggulan dibanding pesaing, seperti adanya lokasi penjualan yang dinilai lebih strategis, lebih mewah, lebih nyaman, pelayanan yang lebih cepat tanggap, atau jika merasa yakin bahwa sudah memiliki pelanggan yang setia. Namun, jika pelaku usaha merasa tidak memiliki keunggulankeunggulan tersebut, maka akan lebih baik jika dilakukan penetapan harga jual yang seidkit lebh rendah dibandingkan dengan harga para pesaing, meskipun hal tersebut tidak memiliki arti harus memangkas keuntungan. Marjin keuntungan harus dapat terpenuhi, yaitu dapat berkisar pada angka $10-20 \%$

Target Costing didefinisikan sebagai suatu langkah penentuan biaya atas suatu produk atau jasa dengan dasar harga yang kompetitif, sehingga produk atau jasa tersebut dapat memenuhi target laba yang telah ditetapkan atau diharapkan. Target Costing merupakan cara penentuan biaya didasarkan pada sitem harga yang kompetitif sehingga penerapan Target Costing harus dapat mengadopsi ukuran dalam penurunan biaya yang ketat. Harga dikatakan menjadi kompetitif jika memenuhi target laba yang diinginkan, menutupi biaya yang memang dikeluarkan dalam memproduksi suatu barang atau jasa.

Dengan demikian target costing akan mejadikan perusahaan lebih kompetitif, dimana Target Costing ini dapat dijadikan suatu strategi umum dalam menjalankan bisnis terutama di saat menghadapi persaingan ketat dengan perbedaan yang sangat kecil dalam penentuan harga jual dalam rangka memenangkan perhatian para konsumen, terlebih lagi jika barang tersebut bersifat subtitutif.

\section{Permasalahan Mitra}

Berdasarkan uraian yang telah dipaparkan pada sub bab sebelumnya, maka dapat disimpulkan pentingnya penentuan harga jual bagi keberlangsungan suatu UMKM di manapun. Hasil komunikasi awal tim pengabdian dengan calon mitra yaitu pelaku UMKM di Kota Jambi, khususnya Dapur Pipit menunjukkan bahwa UMKM Dapur Pipit saat ini belum menguasai ketrampilan serta pemahaman yang cukup mengenai pentingnya penetapan harga pokok produksi dengan tepat bagi usaha mereka. Mitra saat ini belum melakukan perhitungan atau penentuan harga pokok produksi yang merupakan suatu dasar dalam penentuan harga jual, hal terebut dikarenakan belum cukupnya kemampuan mitra dalam melakukan perhitungan harga pokok produksi. Umumnya mitra menentukan harga jual berdasarkan harga pasar.

Dapur pipit merupakan satu jenis UMKM yang dibawahi oleh seorang wirausaha bernama Ibu Fithry. UMKM yang bergerak di bidang kuliner ini memiliki modal usaha sebesar kurang dari Rp10.000.000,- per bulannya dengan usaha inti bisnis puding gelas. Mitra memiliki lokasi di Kabupaten Jelutung, Jambi. Target pemasaran dari mitra adalah para rumah tangga sekitar area 
kompleks tempat tinggal. Dapur pipit memasarkan puding hasil produksinya melalui warung kecil yang dibuka di teras rumah sang pemilik. Omset per hari dari warung ini adalah sebesar Rp300.000,-. Bisnis yang berjalan dikatakan cukup lancer dan sudah memiliki pelanggan tetap. Namun pemilik bisnis mengakui bahwa kelemahan dari pengelolaan terkait keuangan masih menjadi suatu pertanyaan besar.

Saat ini, mitra juga belum mampu secara efisien melakukan penentuan besaran perolehan atas laba dan rugi dari kegiatan usaha yang dijalankan, serta belum dapat memastikan efisiensi dari proses produksi telah berlangsung saat ini, sehingga mitra tidak dapat memahami perkembangan atas usaha yang sedang berjalan.

Mitra juga mengalami kesulitan dalam pengolahan modal yang dimiliki serta pengalihan laba yang diperoleh. Seringkali pengalihan laba yang diperoleh menjadi modal menjadi tidak maksimal karena ada pengaruh kurangnya bahan produksi atau meningkatnya harga bahan baku secara mendadak di pasaran. Mitra juga lebih lanjut memaparkan bahwa belum adanya pencatatan atas segala transaksi penjualan yang terjadi. Dimulai dengan tidak adanya pencatatan atas pembelian bahan baku, proses produksi, dan pemasukan. Selama ini, mitra hanya melakukan pencatatan sederhana dengan mengingat dan menggunakan penilaian pribadi saja

\section{Solusi Permasalahan}

Untuk mengatasi permasalahan yang dihadapi oleh mitra maka tim Abdimas Fakultas Ekonomi dan Bisnis Universitas Tarumanagara memberikan solusi berupa kegiatan pendampingan dan pelatihan mengenai praktek perhitungan unit cost, penentuan harga jual produk, dan pencatatan keuangan yang teoritis dan praktikal. Tim juga menilai bahwa perlu diberikan suatu pelatihan pendampingan mengenai pemahaman mengenai pentingnya perhitungan harga pokok produksi bagi dalam menjalankan bisnis, kemudian adanya pelatihan penentuan besaran harga pokok produksi secara konseptual dan praktik pelaksanaan. Dilanjutkan dengan pemberian bimbingan secara teknis mengenai proses pencatatan ke dalam jurnal serta terkait proses penyusunan laporan laba rugi. Pelatihan tersebut juga sekaligus dilakukan pendampingan terkait bagiamana penentuan dari harga jual suatu produk atau jasa.

Pelatihan serta pendampingan akan memaparkan terkait dengan biaya produksi yang akan meliputi pelatihan pengenalan biaya bahan mentah, tenaga kerja dan overhead produksi (Setiadi, Saerang \& Runtu, 2014). Penyampaian manfaat mengetahui harga pokok produk adalah antara lain (1) proses penentuan harga jual, (2) realisasi biaya, (3) penentuan laba/rugi, dan (4) penetapan harga pokok persediaan untuk barang jadi dan barang dalam proses (Pandini \& Nurchayati, 2018).

Pelatihan juga memaparkan terkait pentingnya perhitungan harga pokok produksi mengingat kegunaan dari adanya suatu informasi harga pokok produksi itu sendiri adalah pada akhirnya untuk perolehan harga jual produk atau jasa. Kemudian pemaparan mengenai kesalahan dalam menghitung harga pokok produksi yang dapat menyebabkan kesalahan dalam penentuan harga jual produk agar tidak terjadi penentuan harga jual produk ditetapkan terlalu tinggi atau bahkan terlalu rendah mengingat, suat penetapan harga jual yang terlampau tinggi atau mahal pada akhirnya akan menimbulkan dampak yang tidak baik bagi pelaku usaha. Lebih lanjut, jika kondisi tersebut terjadi tentunya dapat mengakibatkan produk atau yang ditawarkan menjadi sangat sulit untuk memenangkan persaingan terutama jika disandingkan dengan produk-produk sejenis yang di pasaran. Sebaliknya penetapan harga jual produk atau jasa yang terlalu rendah pada akhirnya mengakibatkan perolehan laba yang juga rendah yang akan berujung pada kebangkrutan dari pelaku usaha.

Selain itu pelatihan juga dirancang agar dapat mengarahkan mitra untuk dapat secra mandiri dalam melakukan penentuan harga jual mengingat ketepatan dalam mengkalkulasi harga pokok produksi akan dapat membantu proses evaluasi perusahaan terkait apakah pelaku bisnis telah 
melakukan proses produksi yang efisien atau sebaliknya. Atas dasar data dari biaya produksi, maka pelaku bisnis juga dapat melakukan identifikasi atas komponen biaya mana saja yang merupakan sumber terjadinya suatu pemborosan, sehingga pelaku bisnis dapat dengan segera melakukan koreksi yang diperlukan agar pada akhirnya diperoleh biaya produksi yang lebih optimal (Sujarweni, 2016). Penyampaian data harga pokok produksi juga dapat dimanfaatkan untuk perhitungan laba/rugi yang riil dari para pelaku usaha. Dari situ juga dapat diperoleh informasi terkahit perkembangan bisnis yang sedang berjalan. Lebih lanjut, informasi terkait harga pokok produksi juga akan sangat membantu untuk melakukan perhitungan besaran persediaan, baik untuk persediaan barang dalam proses maupun barang jadi.

Tim Abdimas juga akan melakukan pelatihan terkait bagaimana menyusun laporan Laba/Rugi dan laporan posisi keuangan yang nantinya juga dapat dijadikan dasar dalam pengajuan permohonan modal ke bank atau lembaga keuangan sejenis lainnya. Bagi bank atau suatu lembaga keuangan, informasi yang ditampilkan dalam laporan tersebut merupakan salah satu dasar untuk dapat dilakukannya proses evaluasi atas kelayakan dari setiap calon nasabah. Sehingga jelas bahwa kemampuan para pelaku bisnis termasuk UMKM dalam menuiapkan semua laporan tersebut memiliki dampak yang signifikan untuk mengatasi segala permasalahan keuangan lain yang umumnya biasa dihadapi para pelaku bisnis termasuk UMKM, terutama dalam kesulitan permodalan.

Pelatihan dan pendampingan lebih lanjut juga akan memprioritaskan pada pengumpulan harga pokok produksi yang kemungkinan besar ditentukan oleh proses produksi yang dilakukan oleh para pelaku bisnis termasuk UMKM. Menurut Daldjono (2011), terdapat dua metode penentuan harga pokok produksi, yaitu metode harga pokok pesanan dan harga pokok proses, atau lebih lanjut dikenal sebagai job order costing dan process costing. Metode harga pokok pesanan adalah metode penentuan biaya produksi atas dasar pesanan dengna tujuan penentuan harga pokok produk yang datang dari setiap pesanan baik harga pokok secara keseluruhan dari tiap-tiap pesanan maupun harga pokok per unit. Pada metode ini, biaya-biaya produksi dikumpulkan untuk pesanan tertentu dan harga pokok produksi per unit dihitung dengan cara membagi total biaya produksi untuk pesanan tertentu dengan jumlah unit produk dalam pesanan yang bersangkutan. Dalam metode harga pokok pesanan, biaya produksi dikelompokkan ke dalam tiga kategori yaitu biaya bahan langsung, biaya tenaga kerja langsung, dan biaya overhead.

Sementara itu, metode harga pokok proses adalah metode pengumpulan harga pokok produksi yang digunakan oleh perusahaan yang mengolah produknya secara masa. Perhitungan harga pokok produk persatuan dilakukan dengan cara membagi total biaya produksi yang dikeluarkan dengan selama periode tertentu dengan satuan produk yang dihasilkan selama periode yang bersangkutan. Perhitungan dilakukan setiap akhir periode. Menurut metode ini, biaya produksi terdiri atas biaya bahan, biaya tenaga kerja, dan biaya overhead (Herawaty \& Mansur, 2019).

\section{METODE PELAKSANAAN PKM}

Kegiatan pengabdian ini dilaksanakan dalam waktu 8 (delapan) minggu dan pelaksanaan pelatihan adalah 2 (dua) hari. Secara keseluruhan rincian waktu pelaksanaan kegiatan adalah sebagai berikut:

1. Persiapan dan komunikasi awal dengan mitra

Pada tahap persiapan dan komunikasi awal ini tim pengabdian melakukan pertemuan daring dengan mitra untuk melakukan analisis situasi dan kebutuhan dari mitra. Kemudian tim memberikan informasi mengenai pelatihan serta pendampingan yang dapat dilakukan untuk mitra. Pelaksanaan tahap ini memerlukan waktu selama satu minggu.

2. Penyusunan modul pelatihan 
Setelah mengetahui permasalahan yang dihadapi mitra, Tim menyiapkan solusi. Pada tahap ini dilakukan penyusunan modul dan kasus yang akan digunakan dalam pelatihan selama dua hari. Pelaksanaan tahap ini memerlukan waktu selama dua minggu.

3. Pelatihan

Pengabdian dalam bentuk pelatihan secara daring akan dilaksanakan dalam waktu dua hari.

4. Evaluasi dan Monitoring

Evaluasi dan monitoring kegiatan dilaksanakan melalui dua cara, yaitu evaluasi pada pelatihan hari kedua dan pendampingan selama dua minggu.

5. Penyusunan laporan

Kegiatan pengabdian kepada masyarakat ini diakhiri dengan penyusunan laporan pengabdian selama tiga minggu.

\section{HASIL DAN PEMBAHASAN}

Kegiatan dilakukan secara daring dengan dihadiri terutama oleh pemilik dari UMKM Dapur Pipit yang selanjutkan disebut sebagai mitra beserta staff yang mengelola bagian keuangan. Pihak mitra menyampaikan paparan mengenai kegiatan yang telah berlangsung saat ini disertai permasalahan yang dihadapi. Secara umum, usaha yang dilakukan tergolong lancar dan sukses, selalu terjadi transaksi penjualan, terkadang tanpa sisa dan terkadang terdapat sisa atas produk makanan yang dijual. Namun, produk tersebut biasanya habis sebelum memasuki masa kadaluarsa. Pemilik menyampaikan bahwa modal yang digunakan seringkali tidak tercatat besarannya, juga laba atau rugi yang terjadi sehari-hari sepertinya berlalu begitu saja. Penentuan harga dan jumlah penjualan juga dilakukan atas dasar perkiraan saja, begitu pula alokasi laba maupun solusi atas kerugian yang terjadi pada hari tersebut.

Setelah pihak mitra menyampaikan kondisi UMKM yang berlangsung serta permasalahannya, tim abdimas menyampaikan pengantar teori terkait perolehan laba secara sederhana, yaitu selisih dari penjualan dengan seluruh biaya yang dikeluarkan. Sehingga dalam hal ini, pihak mitra harus memiliki sistem pembukuan yang tercatat rapih dalam segala detil kegiatan agar dapat mengklasifikasikan mana saja yang termasuk pemasukan kas dan mana saja yang termasuk dalam kategori pengeluaran atau biaya. Lebih lanjut disampaikan bentuk laporan keuangan sederhana, yaitu laporan keuangan yang hanya memasukan total penjualan serta rincian total biaya sehingga berakhir pada perolehan laba.

Terakhir, bagaimana pengelolaan laba atau rugi yang diperoleh dengan menggunakan sistem persentase sebagaimana yang dilakukan oleh perusahaan go public, yaitu penentuan sekian persen sebagai sebagai laba ditahan yaitu untuk modal bagi produksi berikutnya, dan sekian persen sebagai dividen atau keuntungan yang dapat dinikmati oleh mitra.

Sesi pelatihan kemudian dilanjutkan dengan memberi kesempatan selama 24 jam sampai keesokan harinya dilakukan pertemuan daring kembali dengan hasil mitra telah melakukan pencatatan seluruh total penjualan yang diperoleh dan seluruh biaya yang dikeluarkan untuk transaksi penjualan pada hari tersebut. Kemudian dilanjutkan dengan membantu mitra membuat laporan keuangan sederhana, yang terdiri dari total penjualan, harga pokok penjualan, biaya variabel dan tetap, yang diakhiri dengan laba bersih. Dari laba bersih dialokasikan sesuai dengan keinginan mitra, 70 persen sebagai dana untuk produksi keesokan harinya (laba ditahan), dan 30 persen untuk dinikmati oleh mitra untuk keperluan di luar dari usaha yang dijalankan mitra.

Di akhir sesi, mitra memperoleh kemampuan untuk memahami penyusunan laporan keuangan sederhana dan bagaimana mengolah keuntungan atau kerugian yang pada akhirnya diperoleh per satu periode, dalam kasus sederhana tersebut, baru dilakukan per periode hitungan hari. 


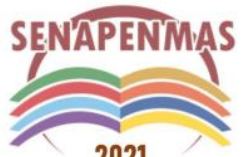

2021
Seminar Nasional Hasil Penelitian dan Pengabdian Kepada Masyarakat 2021 Pengembangan Ekonomi Bangsa Melalui Inovasi Digital Hasil Penelitian dan Pengabdian Kepada Masyarakat Jakarta, 21 Oktober 2021

\section{KESIMPULAN DAN SARAN}

Berdasarkan kegiatan abdimas yang telah dilakukan bersama mitra, dalam hal ini UMKM Dapur Pipit, Jambi, maka dapat disimpulkan beberapa hal, antar lain, kegiatan abdimas telah berjalan dengan baik. Mitra telah menguasai teori penentuan harga dan jumlah penjualan, penyusunan laporan keuangan sederhana, dan pengalokasian laba maupun cara mengatasi kerugian. Mitra telah memahami bahwa disiplin pencatatan lalu lintas keuangan sangat penting untuk selalu dilakukan.

Tim abdimas menyarankan agar mitra dapat melakukan pembukan secara lebih rapih untuk periode yang lebih lama dengan merekap seluruh transaksi keuangan yang terjadi per hari. Implikasi dari kegiatan ini adalah dengan terbantunya mitra untuk melakukan disiplin pembukuan karena pada akhirnya dapat membantu mitra jika pada akhirnya mitra memutuskan untuk mengambil bantuan pinjaman ke lembaga-lembaga keuangan.

\section{REFERENSI}

Djumali, I. (2014). Perhitungan Harga Pokok Produksi Menggunakan Metode Variable costing Dalam Proses Penentuan Harga jual Pada PT. Sari Malalugis Bitung. Jurnal Berkala Ilmiah Efisiensi, 14(2).

Hammer, L. H., Carter, W. K., \& Usry, M. F. (1994). Cost accounting. South-Western Pub.

Herawaty, N., \& Mansur, F. (2019). PPM Perhitungan Harga Pokok Produksi Untuk Efisiensi Biaya Produksi Pada Industri Tahu di Kecamatan Jaluko Kabupaten Muaro Jambi. Jurnal Karya Abdi Masyarakat, 3(1), 15-21.

Pandini, R. I., \& Nurchayati. (2018). Evaluasi Penentuan Harga Pokok Produksi CV. Lira Pratama Semarang. Serat Acitya - Jurnal Ilmiah UNTAG Semarang, 7(1), 1-11.

Rudjito. (2003). Peran Lembaga Keuangan Mikro dalam Otonomi Daerah Guna Menggerakkan Ekonomi Rakyat dan Menanggulangi Kemiskinan. Jurnal Ekonomi Rakyat Th. II ñ No.1-Maret 2003, www.ekonomirakyat, tanggal 4 Januari 2009.

Setiadi, P., Saerang, D. P. E., \& Runtu, T. (2014). Perhitungan Harga Pokok Produksi dalam Penentuan Harga Jual pada CV. Minahasa Mantap Perkasa. Jurnal Berkala Ilmiah Efisiensi, 14(2), 70-81.

Sujarweni, V. W. (2016). Implementasi Penentuan Harga Pokok Produksi Untuk Mencapai Laba Optimal (Studi Pada Sentra Ukm Industri Bakpia Di Wilayah Minomartani Sleman Yogyakarta). Jurnal Riset Akuntansi dan Keuangan, 4(3), 1111-1124. doi: 10.17509/jrak.v4i3.4665 
Seminar Nasional Hasil Penelitian dan Pengabdian Kepada Masyarakat 2021

Pengembangan Ekonomi Bangsa Melalui Inovasi Digital Hasil Penelitian dan

Pengabdian Kepada Masyarakat

Jakarta, 21 Oktober 2021

(halaman kosong) 